\title{
Understanding Processes Affecting Mineral Deposits in Humid Environments
}

Recent interdisciplinary studies by the U.S. Geological Survey (USGS) have resulted in substantial progress toward understanding the influence that climate and hydrology have on the geochemical signatures of mineral deposits and the resulting mine wastes in the eastern United States. Specific areas of focus include the following:

- Release, transport, and fate of acid, metals, and associated elements from inactive mines in temperate coastal areas.

- Release, transport, and fate of metals from unmined mineral deposits in tropical to subtropical areas.

- Influence of climate, geology, and hydrology on remediation options for abandoned mines.

- Application of radiogenic isotopes to uniquely apportion source contributions that distinguish natural from mining sources and extent of metal transport.

\section{Overview}

The environmental effects of abandoned mines and unmined mineral deposits result from a complex interaction of a variety of chemical and physical factors. These include the geology of the mineral deposit, the hydrologic setting of the mineral deposit and associated mine wastes, the chemistry of waters interacting with the deposit and associated waste material, the engineering of a mine as it relates to the reactivity of mine wastes, and climate, which affects such factors as temperature and the amounts of precipitation and evapotranspiration; these factors, in turn, influence the environmental behavior of mineral deposits. The role of climate is becoming increasingly important in environmental investigations of mineral deposits because of the growing concerns about climate change.

Identifying the most important processes affecting the environmental behavior of mineral deposits is often difficult because of the complications arising from multiple physical and chemical processes working simultaneously; this identification is essential for effective mitigation or remediation. These distinctions are even more difficult to make in such settings as the eastern United States where there are seasonal changes in temperature and precipitation. Coastal areas are additionally challenging because effects involve both fresh and sea water. Bulk geochemical techniques based on the mass balance of major elements commonly yield ambiguous results. Instead, advanced geochemical techniques are needed, such as stable and radiogenic isotope analysis and trace element analysis of various inorganic and organic media. In the context of detailed mineralogical and geochemical characterization of samples, these techniques are needed to isolate or trace the key factors controlling the environmental effects of abandoned mines and unmined mineral deposits.

The recently completed USGS project entitled "Tracers of Surficial Processes Affecting Mineral Deposits in Humid Environments" addressed these issues at a variety of sites in the eastern United States. Results from these studies have increased our understanding of the complex interplay of physical and chemical processes contributing to the release, transport, and fate of potentially toxic elements around unmined deposits and abandoned mines in the humid climate of the eastern United States. These interdisciplinary studies provide the basis for scientific decisionmaking for land management and mine remediation agencies. The research has involved cooperation with a broad spectrum of stakeholders, including local, State, and Federal agencies, academia, and nongovernmental organizations. Current USGS research highlights the importance of understanding the role of multiple sources and sinks as they relate to the flux of metals and other trace elements from mine waste piles on the shores of an estuary with a submerged, flooded mine pit; the effects of warm climates and high rainfall on the geochemical signatures of unmined copper deposits in mountainous tropical settings; and the implications for remediation in temperate climates of the release, transport, and fate of a variety of contaminants from abandoned metallic and nonmetallic mines in the eastern United States. Experts in the fields of biology, economic geology, geochemistry, hydrology, and mineralogy joined forces for a series of studies that investigated these topics on scales ranging from the microscopic to the watershed. Highlights included the following:

- Integrated detailed geochemical, mineralogical, and radiogenic isotope studies of bedrock, ore, mine waste, sediments, and aquatic biota (clams, lobsters, crabs) at the Callahan Mine Superfund site near Harborside, Me., included an inventory of the natural and mining sources of redistributed metals in sediment profiles deposited before, during, and after mining operations within the flooded pit, estuarine, and offshore environment.

- Baseline geochemical characterization of rocks, surface water, and sediments around unmined porphyry copper deposits in the Cordillera Central mountain range in Puerto Rico could have important global implications for closure goals for porphyry copper deposits worldwide.

- Multidisciplinary studies of abandoned metallic and nonmetallic mines in temperate climate settings throughout the eastern United States demonstrated the importance of understanding the complex interactions of mine wastes with water and the atmosphere for the scientific-based decisionmaking process for remedial actions at these sites.

- Geochemical and mineralogical studies of arsenical pesticides historically used in agricultural practices of the eastern United States documented the legacy of arsenical pesticide use, including the determination of diagnostic geochemical and radiogenic isotope features to distinguish pesticides from natural and mining metal sources.

- A multidisciplinary geochemical, hydrologic, mineralogical, and radiogenic isotope study in Pennsylvania of a contaminated watershed containing water and soils with anomalously high lead and arsenic led to identification and apportionment of the natural (bedrock) and anthropogenic (agricultural, anthropogenic, or mining) sources of released metals.

- Detailed geochemical, mineralogical, and radiogenic isotope studies of soils and ground waters in southern Italy focused on the processes that controlled metal redistribution as a result of changing land-use practices, ranging from rural to heavily populated urban regions.

\section{Geoenvironmental Studies}

\section{Humid Coastal Regions}

Metals and acidity are released from sulfide-rich mine wastes at abandoned metal mines and can commonly be carried for many kilometers downstream in fresh water watersheds. However, interactions of mine drainage with alkaline brackish waters found 
in estuaries generated atypical geochemical reactions compared with results expected based on well-studied freshwater systems. In addition, the growing demand for mineral resources and a trend to mine larger deposits will likely result in the submarine disposal of mine wastes receiving increased consideration in the future. Therefore, the results of this USGS research on the environmental impacts of abandoned mines in the eastern United States, including large-scale regional isotopic studies of coastal watersheds in Maine and New Hampshire (Ayuso and Foley, 2008), mineral sources and transport pathways for metals release (Foley and Ayuso, 2008), and focused studies at the Callahan Mine Superfund site will have far-reaching implications. In order to examine the flux of metals and related compounds from mine waste piles onshore to the estuary, samples of mine waste, mine drainage, estuary waters and sediments, and invertebrates were collected and examined in the laboratory for geochemical and other changes that trace the movement of these elements (figs. 1 and 2). Methods such as electron microscopy, bulk geochemical analysis, geochemical modeling, isotopic analysis, laser ablation microanalysis, optical microscopy, quantitative x-ray diffraction, and surface-area analysis were used to determine the complex pathways of contaminants from source to marine biota.
Radiogenic isotope variations [lead, neodymium, and (or) strontium] and mineralogical and trace element data chronicle metal redistribution among host rocks, ore, waste piles, estuary sediments, and aquatic biota (affecting bivalves and possibly crabs and lobsters). Microanalyses of bivalve shells collected from sediment cores show distinct metal-rich zones and variable metal contents for copper, zinc, and lead that closely parallel variations in metal contents of enclosing sediments. Isotope compositions vary widely, linking host rocks, ore, sediment, and clam shells. Lead isotopic signatures of sediments span a range from host to massive sulfide to waste. This isotopic range overlaps signatures of bivalve shells and water from the former open pit and areas adjacent to the site.

The chemical and isotopic variations in estuary sediments reflect core depth, bulk mineralogy, and proximity to waste piles. The bivalves likely incorporated lead and other metals by ingestion of fine particulate matter in addition to dissolved metals. The lead isotope and trace element data show a link between mining and ore processing and the fate of metals that are redistributed in estuary sediments and aquatic biota. Within and immediately adjacent [0-2 kilometers $(\mathrm{km})]$ to the site, sediment and shells show elevated levels of metals; however, less than $4 \mathrm{~km}$ away from the mine site, the impact of mining is essentially indistinguishable from background levels.

Investigations of the flooded 100meter (m)-deep pit in the estuary identified permanent stratification of the water column because of the mixing of less dense freshwater draining from the surrounding watershed with sea water entering the estuary from tidal action. This permanent stratification includes anoxic bottom waters in the pit where microbial activity converts dissolved sulfate in sea water into sulfide. This effectively removes metals from the water column, overall rendering the metals less toxic to the surrounding ecosystem.

The insights gained from detailed examination of the Callahan Superfund mine site are influencing the decisionmaking process for remediation options at the site and can provide sagacity for waste management strategies at coastal-setting mines globally.

\section{Land Use and the Legacy of Agricultural Practices}

Another aspect of this study has been to investigate the legacy of land-use evolution, metal redistribution, and the distinction between natural and human-derived sources on the surface environment. This work has involved an assessment of the chemical changes in soils and waters in areas that have
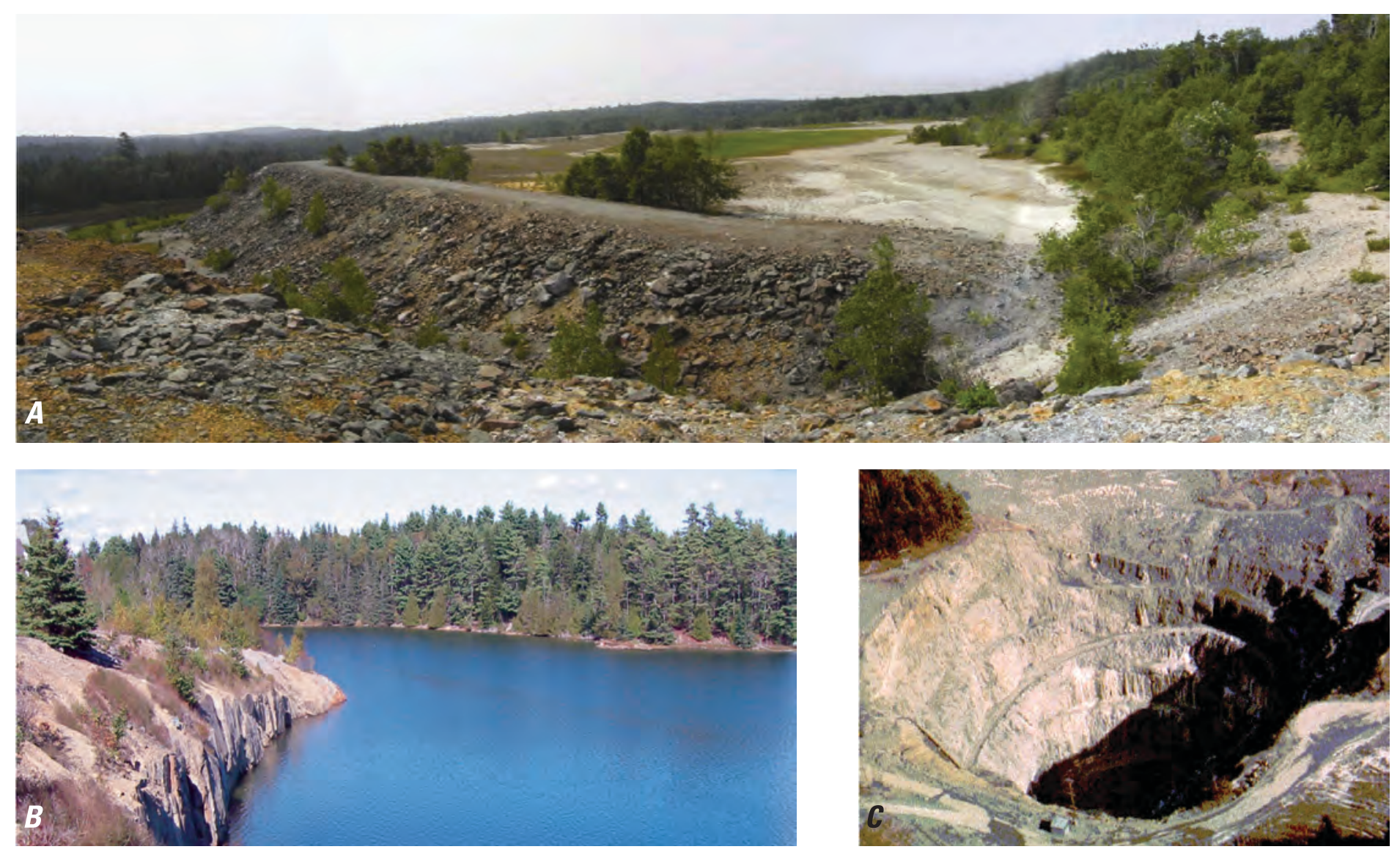

Figure 1. At the Callahan Mine Superfund site on the coast of Maine, the Goose Pond estuary was drained and mined by open pit methods. After the mine closure, the pit was flooded. Mining and ore processing activities contributed to the release of metals that are now distributed in host rocks, ore, tailings and waste piles, stream and estuary sediments, and aquatic biota. $A$, Callahan site tailings pile; photograph by Robert Ayuso, U.S. Geological Survey. $B$, Site of the former open pit in 2005; photograph by Robert Ayuso, U.S. Geological Survey. C, Open pit in 1972; photograph by U.S. Environmental Protection Agency. 

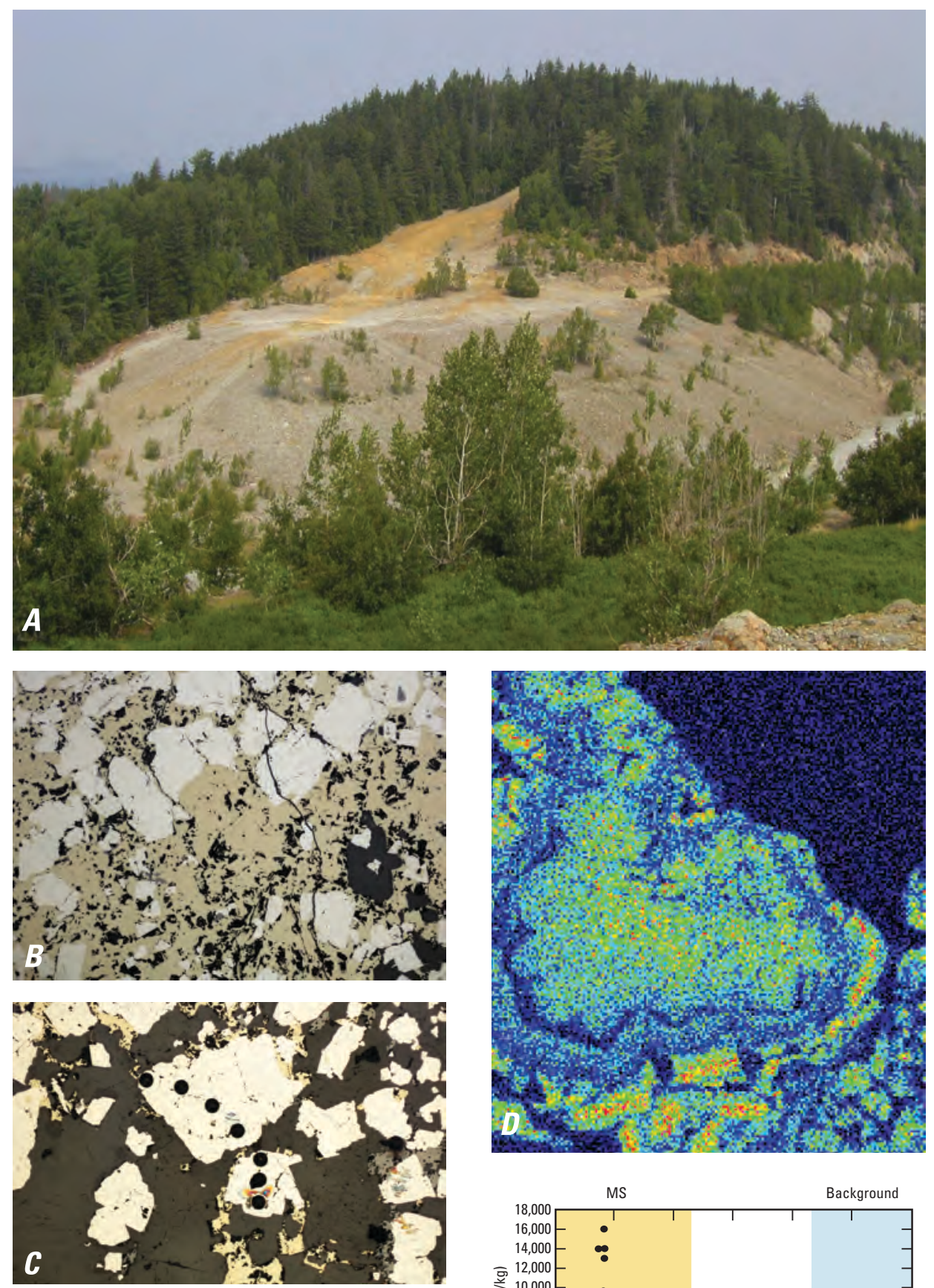

Figure 2. Field studies of background bedrock and sediments, mine waste materials, and estuary sediments and biota were conducted for selection of materials for detailed microchemical analyses to determine mineralogical and trace element variability and to develop isotopic tracer methods for discriminating ore from natural background conditions. $A$, Callahan Mine Superfund site, Me.; photograph by Robert Ayuso, U.S. Geological Survey. B, Pyrite and chalcopyrite ore. $C$, Laser analyses of metals in pyrite. $D$, Arsenic map, showing relative microscopic variations in the concentration of arsenic; warmer colors (red and orange) represent higher concentrations of arsenic, whereas cooler colors (blue and green) represent lower concentrations. E, Graphs of concentrations of lead $(\mathrm{Pb})$, copper $(\mathrm{Cu})$, and zinc $(\mathrm{Zn})$, in parts per million (ppm), versus the ratio of lead isotopes $\left({ }^{206} \mathrm{~Pb} /{ }^{207} \mathrm{~Pb}\right)$; yellow area is massive sulfide ore (MS), white area is main field, and blue area is the background. been affected by agricultural, suburban, and urban human activities related to industrial, manufacturing, or municipal processes.

The lead isotopic compositions of pesticides commonly used in the United States until 1988, such as lead arsenate, sodium meta-arsenite, and calcium arsenate, were studied in order to better establish anthropogenic sources of lead and arsenic in soils and waters. Applying this information to past agricultural practices, scientists evaluated the sources of lead in residential water wells and soils from the former Mohr Orchards near Allentown, Pa., a U.S. Environmental Protection Agency (EPA) Superfund site and an area that has evolved from rural to suburban. The levels of lead content in residential waters are of concern for possible adverse effects on human health. Lead isotopic compositions of surface and well waters, arsenical pesticides, local soils and bedrock, and other anthropogenic sources of lead were measured to identify potential natural and anthropogenic sources (Ayuso and others, 2008). The well water samples show systematic isotope variations. Soils enriched in lead and arsenic could have supplied relatively unradiogenic lead to the well waters. Lead arsenate pesticide of the type that may have been extensively used in the area cannot exclusively account for the range of lead isotopic compositions of the well waters and soils. Industrial lead is favored as the predominant source (in addition to contributions from pesticide-rich soils) into the well waters.

\section{International Land Use Practices}

Understanding the impacts of historical land-use practices on modern life is of great concern to the national and international community in developing strategies to cope with environmental conditions associated with aging rural-to-urban infrastructure. To better understand the global effects of environmental conditions, research involved joint studies with academic institutions in the European Union that focused on soil and water geochemistry.

To examine the processes that control metal redistribution as a result of changing land-use practices, the chemical composition of surface soil samples, soil profiles, and groundwaters in the Campania region of Italy were studied. The impact of human activity is most intense in the highly urban areas (so called brownfields) and least intense in rural areas. In urban areas, anthropogenic sources, such as automobile traffic, industrial activities, municipal waste, and other manufacturing point sources, are likely the main causes for the anomalously high metal contents (lead, arsenic, cadmium, zinc) and unique radiogenic isotope signatures of soils and groundwaters. In rural areas, the point sources are dominated by metals from atmospheric deposition (from industrial processes and from the burning of fossil fuels), 
by contributions from past agricultural practices, and by the natural sources of metals from the area's geologic background.

\section{Weathering of Aluminosilicate Minerals}

Aluminous minerals occur in a variety of mineral deposit types (metallic and nonmetallic) found in humid ecosystems. Aluminum-hydroxide flocculates in contaminated streams have a close link to aluminumhydroxide solids and are an important component of contaminated waterways. The degradation of aluminous sources influences the mobility of associated metals in mineral deposits, mineralized rocks, tailings piles, soils, waters, and watersheds because of the chemical and thermodynamic properties of aluminous minerals.

USGS studies were conducted in cooperation with the U.S. Forest Service on the weathering cycle of garnet from source rock to deposition in garnetiferrous ferricretes and gravels. These studies document the impact of primary mineral composition on weathering characteristics and resulting alteration assemblages. Studies conducted in concert with the Conservation Division of the National Park Service on the chemical and physical weathering of the Comte de Rochambeau monument at Lafayette Square Park in Washington, D.C., document changes in mineralogy, porosity, surface reactions, and specific surface area. These parameters may be used to predict degradation rates of carbonate relative to associated aluminosilicate minerals under humid temperate, subtropical conditions. Studies of mineral reactions, surface area, and correlations with aluminosilicate minerals were also conducted in support of the Callahan Mine Superfund site and Allentown studies.

\section{Unmined Mineral Deposits in Tropical and Subtropical Settings}

Unmined mineral deposits are natural geochemical anomalies that can manifest themselves as geochemical haloes in the surrounding rock, in soils, in surface water and groundwater, in nearby stream and lake sediments, and in vegetation. These manifestations of mineral deposits form the basis of the field of exploration geochemistry. Most of the knowledge of the environmental behavior of porphyry copper deposits, the source that supplies most of mined copper today, is based on information from deposits in semiarid or arid regions, such as Arizona. However, because there is significant potential for undiscovered deposits in all climatic settings throughout the world, there is a need to expand the knowledgebase to behavior of deposits in other climatic conditions.

USGS studies around unmined porphyry copper deposits in the Cordillera Central document the influence of hot climates with high rainfall on the environmental expression of porphyry copper deposits (fig. 3).
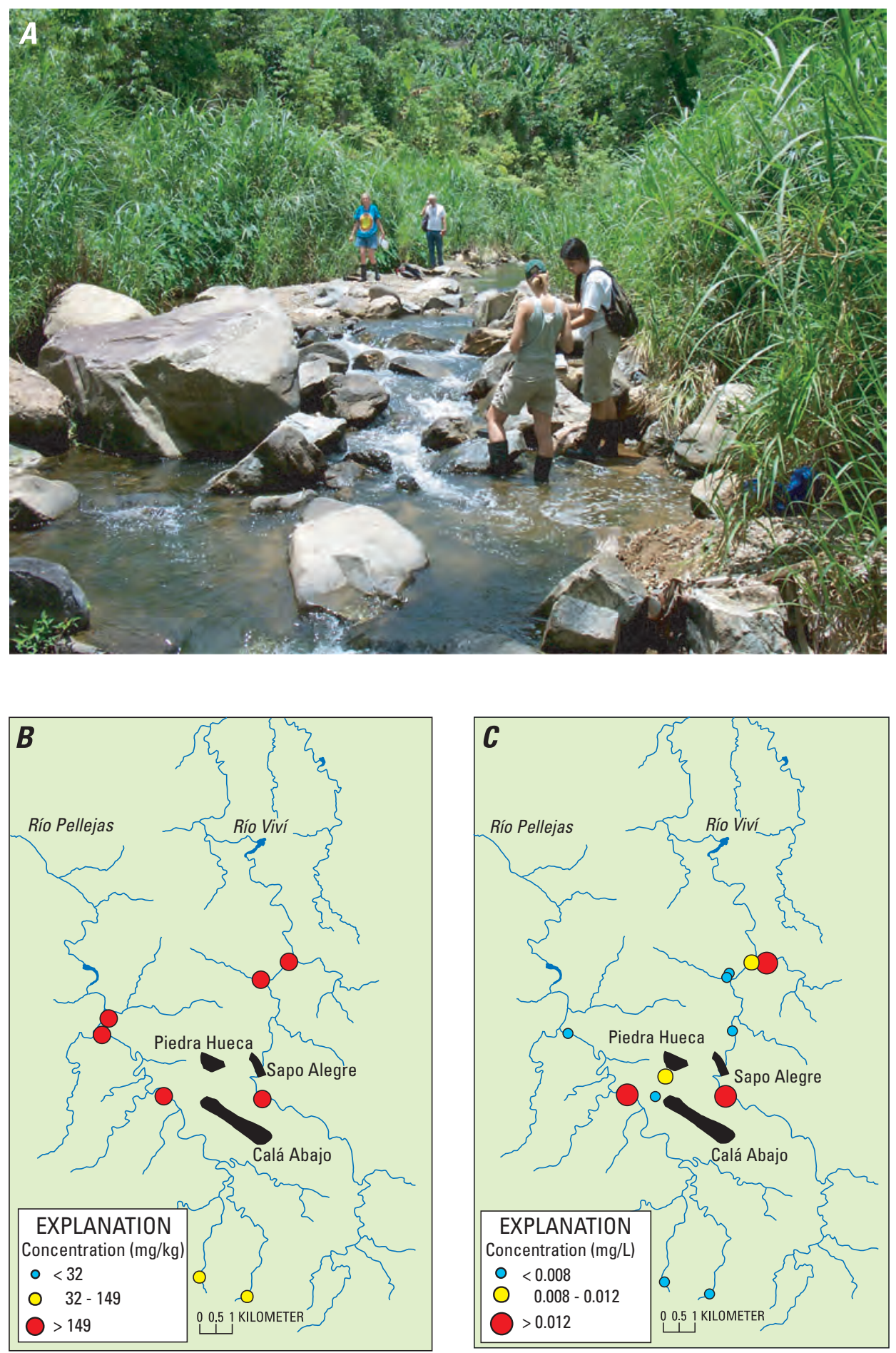

Figure 3. The Cordillera Central of Puerto Rico hosts several unmined porphyry copper deposits. $A$, Photograph of sample site on the Río Viví, Puerto Rico, in the vicinity of deposits; photograph by Robert Seal, U.S. Geological Survey. B, Map showing copper concentrations in sediments, measured in milligrams of copper contained per kilogram of copper ore $(\mathrm{mg} / \mathrm{kg})$. Samples shown as yellow dots have concentrations in excess of the threshold effects concentration of $32 \mathrm{mg} / \mathrm{kg}$ but below the probable effects concentration of $149 \mathrm{mg} / \mathrm{kg}$. Samples shown as red dots have concentrations in excess of the probable and threshold effects concentrations. $C$, Map showing copper concentrations in surface water in milligrams of copper contained per liter of water $(\mathrm{mg} / \mathrm{L})$. Natural copper concentrations in surface waters and springs near the deposits locally exceed short-term $(0.012 \mathrm{mg} / \mathrm{L})$ and long-term $(0.008 \mathrm{mg} / \mathrm{L})$ exposure guidelines set by the U.S. Environmental Protection Agency. Samples shown as yellow dots have concentrations in excess of the long-term exposure guidelines but below the short-term exposure guideline. Samples shown as red dots have concentrations in excess of short-term and long-term exposure guidelines. Black shapes are unmined porphyry copper deposits in figures $3 B$ and $3 C$. U.S. Geological Survey baseline characterization studies of natural geochemical variations in the vicinity of the deposits document natural copper concentrations. 
The extensive weathering of both the host rocks and the mineral deposits has resulted in moderately acidic to moderately alkaline $\mathrm{pH}$ values (5.1-8.9) in the vicinity of the deposits. In terms of dissolved constituents, sulfate shows significant increases downstream of the deposits. Dissolved iron and copper only show localized elevated concentrations downstream of the deposits. Some of the concentrations of copper locally exceed acute toxicity limits for aquatic ecosystems. In contrast, stream sediments show an extensive zone downstream with copper concentrations above the probable effects concentration. All other elements are below their probable effects concentrations (the level of a concentration in the stream sediment that is likely to cause an adverse effect from direct exposure) (MacDonald and others, 2002).
The results of this research provide a better understanding of the environmental characteristics of this important type of copper deposit under the varying conditions found in nature (Berger and others, 2008). Knowledge of premining conditions aids in setting realistic closure goals for future mines and reasonable remediation goals for active and abandoned mines that predate modern regulation.

\section{Science in Support of Mitigation and Remediation}

The chemical complexity of abandoned mines eliminates the possibility of a standard method of remediation that will solve all or most of the environmental problems associated with the mines. The variations in chemical complexity from one mine to another stem from differences in
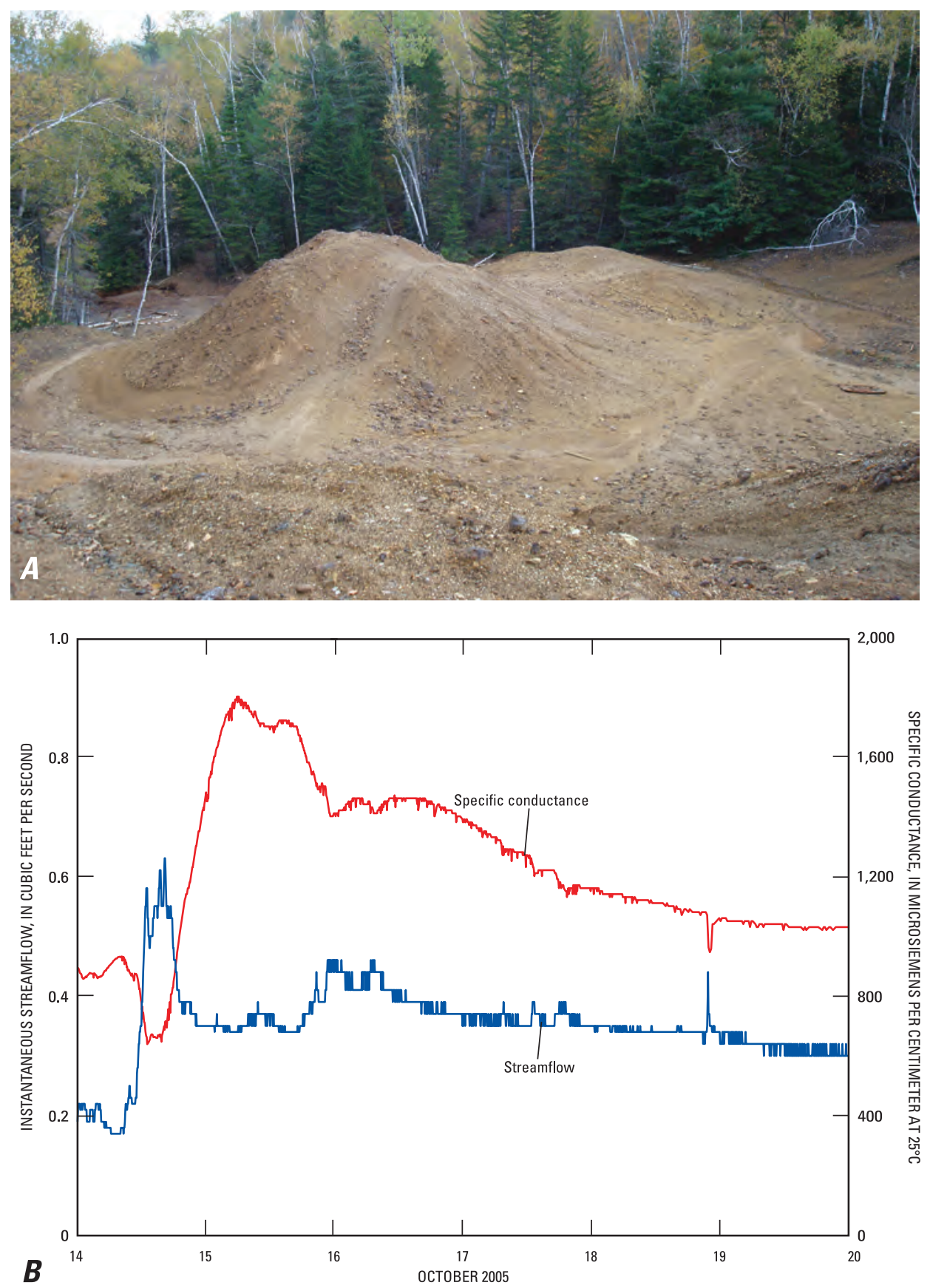

geologic characteristics, mine and ore processing methods, hydrologic settings of the mine and the waste piles, and climatic settings. Recently completed USGS research investigated the role of climate in controlling the environmental impact of abandoned mines in the eastern United States as it relates to potential remediation strategies.

Acid-generating mine wastes from abandoned base-metal mines in the Virginia gold-pyrite belt severely impair watersheds downstream of the waste piles. The impairment of the aquatic ecosystem is exacerbated by the low total dissolved solids found in the watersheds and by evaporative concentration of toxic metals during the hot, dry summer months. These conditions favor the formation of soluble salts, which can cause acute effects during subsequent storm events (Seal and others, 2008). Site remediation by State agencies includes isolation and encapsulation of mine wastes and submersion of residual material to prohibit the evaporative formation of toxic soluble salts.

By contrast, acid-generating mine wastes from abandoned copper mines farther north, in Vermont, can result in the formation of toxic metal-sulfate salts both on the surface of wastes during hot, humid summer months and at depth through evaporation. The evaporation is related to capillary action throughout the year,

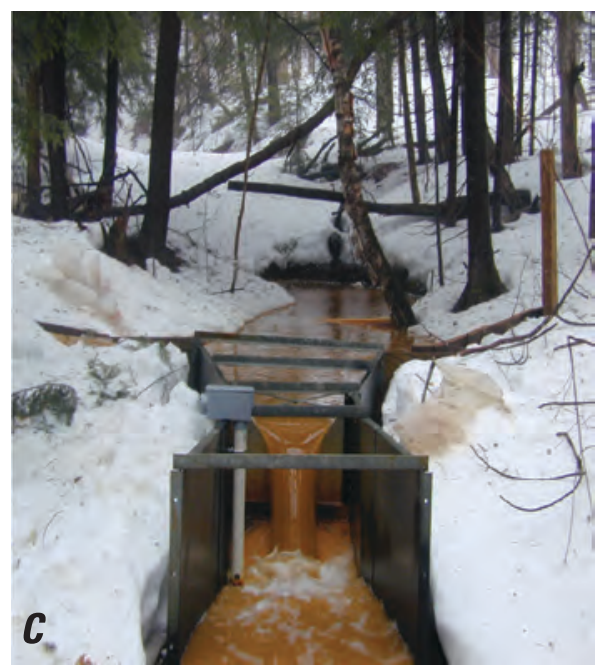

Figure 4. The weathering of sulfuric mine wastes and tailings, as demonstrated in the Pike Hill Mine Superfund, Vt., study, cause the formation of efflorescent sulfate salts on and within waste piles. Spring snowmelt and rain events dissolve and flush the highly soluble salts, resulting in an increase in specific conductance, an increase in dissolved metal concentrations, and a decrease in $\mathrm{pH}$ in downstream waters. $A$, Mine waste piles at the Pike Hill Mine Superfund site; photograph by Robert Seal, U.S. Geological Survey. $B$, Chart showing flushing of efflorescent sulfate salts during rain event in October 2005; $\mathrm{x}$-axis tick marks indicate midnight of the date listed. $C$, Snowmelt and rain flush salts from upstream mine waste; photograph by Richard Kiah, U.S. Geological Survey. 
even when covered by winter-long snow packs (fig. 4). The highest concentrations of base-metal contaminants occur in the spring with snow melt when water is able to saturate the subsurface of the waste piles and dissolve the salts (Piatak and others, 2006; Kiah and others, 2007). Future site remediation by the EPA could involve relocation of the most problematic wastes piles, followed by covering to prevent the infiltration of water.

Mine wastes from an abandoned asbestos mine in northern Vermont have caused significant impairment of nearby wetland habitats largely owing to the erosion and redeposition of waste material. USGS studies documented the formation of magnesium carbonate crusts on the waste piles because of weathering in humid temperate climates (Levitan and others, 2009; Piatak and others, 2009). These crusts may serve two useful purposes. First, the cementation of the surfaces of the piles diminishes the amount of windblown asbestos dispersed from the site to the surrounding areas. Second, the crusts represent a sink for atmospheric greenhouse gases. Future remedial investigations at the site may need to consider the feasibility and positive effects of encouraging these crusts to form under these humid temperate conditions.

\section{Summary}

The recently completed integrated effort of the USGS Mineral Resources Program to understand processes affecting mineral deposits in humid settings highlights the important role that climate plays in controlling environmental effects associated with mineral deposits and their mine wastes.

\section{References Cited}

Ayuso, R.A., and Foley, N.K., 2008, Anthropogenic and natural lead isotopes in Fe-hydroxides and $\mathrm{Fe}$-sulphates in a watershed associated with arsenicenriched groundwater, Maine, USA: Geochemistry: Exploration, Environment, Analysis, v. 8, no. 1, February, p. 77-89.

Ayuso, R.A., Foley, N.K., and Lipfert, G., 2008, Lead isotopes as monitors of anthropogenic and natural sources affecting the surficial environment, chap. 12 of de Vivo, B., Belkin, H.E, and Lima, A., eds., Environmental geochemistry-Site characterization, waste disposal, data analysis, and case histories: Elsevier Publications, p. 292-320.

Berger, B.R., Ayuso, R.A., Wynn, J.C., and Seal, R.R., 2008, Preliminary model of porphyry copper deposits: U.S. Geological Survey Open-File Report 2008-1321, $55 \mathrm{p}$.

Foley, N.K., and Ayuso, R.A., 2008, Mineral sources and transport pathways for arsenic release in a coastal watershed, USA: Geochemistry: Exploration, Environment, Analysis, v. 8, no. 1, February, p. $1-17$.

Kiah, R.G., Deacon, J.R., Piatak, N.M., Seal, R.R., II, Coles, J.F., and Hammarstrom, J.M., 2007, Surface-water hydrology and quality at the Pike Hill Superfund site, Corinth, Vermont, October 2004 to December 2005: U.S. Geological Survey Scientific Investigations Report 2007-5003, 61 p., accessed October 15, 2009, at http://pubs.usgs.gov/sir/2007/5003/.
Levitan, D.M., Hammarstrom, J.M., Gunter, M.E., Seal, R.R., II, Chou, I.-M., and Piatak, N.M., 2009, Mineralogy of mine waste at the Vermont Asbestos Group mine, Belvidere Mountain, Vermont: American Mineralogist, v. 94, p. 1063-1066.

MacDonald, D.D., Ingersoll, C.G., and Berger, T.A., 2000, Development and evaluation of consensus-based sediment quality guidelines for freshwater ecosystems: Archives of Environmental Contamination and Toxicology, v. 39, no. 1, p. 20-31.

Piatak, N.M., Seal, R.R., II, Hammarstrom, J.M., Kiah, R.G., Deacon, J.R., Adams, Monique, Anthony, M.W., Briggs, P.H., and Jackson, J.C., 2006, Geochemical characterization of mine waste, mine drainage, and stream sediments at the Pike Hill copper mine Superfund site, Orange County, Vermont: U.S. Geological Survey Scientific Investigations Report 2006-5303, 120 p., accessed October 15, 2009, at http://pubs.usgs.gov/sir/2006/5303/.

Piatak, N.M., Seal, R.R., II, Levitan, D.M., and Hammarstrom, J.M., 2009, Geochemistry of mine waste, mine drainage, and stream sediments from the Vermont Asbestos Group mine, northern Vermont, USA: International Conference on Acid Rock Drainage, 8th, Skellefteä, Sweden, June 23-26, 2009, [Proceedings], 10 p.

Seal, R.R., II, Hammarstrom, J.M., Johnson, A.N., Piatak, N.M., and Wandless, G.A., 2008, Environmental geochemistry of a Kuroko-type massive sulfide deposit at the abandoned Valzinco mine, Virginia, USA: Applied Geochemistry, v. 23 , no. 2 , p. 320-342.
For more information, detailed descriptions, and complete bibliographies on these and other project-related studies, please visit http://minerals.usgs.gov/east/humid/ index.html.

\section{For more information, contact}

Robert R. Seal

U.S. Geological Survey

954 National Center

Reston, VA 20192

Telephone: 703-648-6290

E-mail: rseal@usgs.gov
Robert A. Ayuso U.S. Geological Survey 954 National Center Reston, VA 20192 Telephone: 703-648-6347 E-mail: rayuso@usgs.gov 